\title{
Activation of $V_{1}$-receptors by vasopressin stimulates inositol phospholipid hydrolysis and arachidonate metabolism in human platelets*
}

\author{
Wolfgang SIESS, Marianne STIFEL, Helge BINDER and Peter C. WEBER \\ Medizinische Klinik Innenstadt der Universität München, Ziemssenstrasse`1, 8 München 2, Federal Republic of Germany
}

\begin{abstract}
The activation of platelet $\mathrm{V}_{1}$-receptors by vasopressin $(0.01-1 \mu \mathrm{M})$ induces the rapid formation of inositol phosphates, 1,2-diacylglycerol and phosphatidic acid, indicating inositol phospholipid hydrolysis by phospholipase C. Vasopressin immediately induces the formation of inositol bisphosphate and inositol trisphosphate. Accumulation of inositol 1-monophosphate and inositol 4-monophosphate occurs later after a time lag of $15 \mathrm{~s}$. Low concentrations (10-100 nM) of vasopressin only activate phospholipase $C$, whereas high concentrations $(1 \mu \mathrm{M})$ induce activation of phospholipase $C$ and subsequently the production of arachidonate metabolites. Cyclo-oxygenase metabolites are associated with further activation of phospholipase $\mathrm{C}$, release reaction and irreversible platelet aggregation. Vasopressin requires for its action extracellular $\mathrm{Mg}^{2+}$, but not $\mathrm{Ca}^{2+}$. The described platelet changes are not induced by 1-desamino-[8-D-arginine]vasopressin, a $\mathrm{V}_{2}$-receptor agonist, and are blocked by a specific $\mathrm{V}_{1}$-receptor antagonist. The results indicate that platelets possess a $\mathrm{V}_{1}$-receptor that is coupled to polyphosphoinositide hydrolysis by phospholipase $\mathrm{C}$, leading to the formation of 1,2-diacylglycerol and inositol trisphosphate. Those compounds may act as second messengers for platelet responses induced by vasopressin, whereas endoperoxides and thromboxane $A_{2}$ stimulated by vasopressin may serve as amplifiers for platelet activation.
\end{abstract}

\section{INTRODUCTION}

Vasopressin induces the pressor and antidiuretic response through activation of two separate receptors, the $V_{1}$ - and $\mathrm{V}_{2}$-receptor respectively (Michell et al., 1979). The receptors are coupled to different intracellular second messengers and differ in their molecular size (Michell et al., 1979; Crause et al., 1984). For example, $\mathrm{V}_{1}$-receptor activation in hepatocytes is related to inositol phospholipid hydrolysis and intracellular $\mathrm{Ca}^{2+}$ mobilization, whereas $\mathrm{V}_{2}$-receptor activation in renal tubular cells leads to an increase of cyclic AMP (Kirk et al., 1977, 1979, 1981; Billah \& Michell, 1979; Michell et al., 1981; Thomas et al., 1984; Charest et al., 1985; Butlen et al., 1978). In addition to phosphoinositide breakdown and cyclic AMP accumulation, vasopressin can also stimulate prostaglandin formation in various cell types (Hassid \& Williams, 1983; Pfeilschifter et al., 1984; Lieberthal \& Levine, 1984; Ausiello \& Zusman, 1984).

In platelets, vasopressin induces shape change, aggregation and release reaction, most probably through activation of $V_{1}$-receptors (Haslam \& Rosson, 1972; M. E. Thomas et al., 1983). Although $\mathrm{V}_{1}$-receptor activation is coupled with an inhibition of adenylate cyclase activity in particulate fractions of platelets, vasopressin does not decrease cyclic AMP levels in intact platelets (Vanderwel et al., 1983). Therefore second messengers, other than a decrease of cyclic AMP, may be involved in platelet activation induced by vasopressin. A wide variety of platelet agonists induces inositol phospholipid cleavage in human platelets by phospho- lipase C (Lapetina \& Cuatrecasas 1979; RittenhouseSimmons, 1979; Broekman et al., 1980; Lapetina, 1982; Lapetina \& Siess, 1983; Siess et al., 1983a,b, 1984a,b, $1985)$ leading to two putative second messengers: 1,2-diacylglycerol activates protein kinase $\mathrm{C}$, and inositol 1,4,5-trisphosphate mobilizes $\mathrm{Ca}^{2+}$ from the endoplasmic reticulum in various cell types (Nishizuka, 1983; Streb et al., 1983; Berridge, 1984). Recently it has been observed that vasopressin increases cytoplasmic $\mathrm{Ca}^{2+}$ in human platelets partly by release from intracellular stores (Hallam et al., 1984). Besides a preliminary report indicating that vasopressin stimulates the formation of phosphatidic acid in platelets (MacIntyre \& Pollock, 1982) nothing is known about the effect of vasopressin on platelet phospholipid metabolism. We attempted, therefore, to study the action of vasopressin on platelet inositol phospholipid metabolism and on production of arachidonate metabolites in relation to specific platelet responses.

\section{EXPERIMENTAL PROCEDURES}

\section{Materials}

[Lysine]vasopressin was obtained from Sigma. 1Desamino-[8-D-arginine]vasopressin (DDAVP, Minirin) was obtained from Ferring (Kiel, Germany). The $\mathrm{V}_{1^{-}}$ receptor antagonist D-( $\left.\mathrm{CH}_{2}\right)_{5} \mathrm{Tyr}(\mathrm{Me})-\mathrm{AVP}$ ('Manning Compound') was purchased from Bachem (Torrance, CA, U.S.A.). [ $\left.{ }^{3} \mathrm{H}\right]$ Inositol was obtained from New England Nuclear Corp. All other materials were obtained as described previously (Siess et al., 1984b).

Abbreviations used: AVP, [8-D-arginine]vasopressin; DDAVP, 1-desamino-[8-D-arginine]vasopressin; PtdIns, phosphatidylinositol; PtdIns4P, phosphatidylinositol 4-phosphate; PtdIns(4,5) $P_{2}$, phosphatidylinositol 4,5-bisphosphate; HHT, 12-hydroxyheptadeca-5,8,10-trienoic acid; 12-HETE, 12-hydroxyeicosa-5,8,10,14-tetraenoic acid.

* Dedicated to Professor Eberhard Buchborn on the occasion of his 65th birthday. 


\section{Measurement of platelet lipids}

Platelet-rich plasma from $200 \mathrm{ml}$ of human blood was incubated for $90 \mathrm{~min}$ at $37^{\circ} \mathrm{C}$ with $400 \mu \mathrm{Ci}$ of $\left[{ }^{3} \mathrm{H}\right]$ arachidonic acid in the presence of prostaglandin $\mathrm{E}_{1}$ $(1 \mu \mathrm{g} / \mathrm{ml})$. Platelets were then centrifuged, washed once with $30 \mathrm{ml}$ of Tyrode/Hepes buffer containing $\mathrm{CaCl}_{2}$ (0.1 mM), $\mathrm{MgCl}_{2}$ (1 mM), heparin (25 units/ml), potato apyrase $(200 \mu \mathrm{g} / \mathrm{ml})$ and prostacyclin $(300 \mathrm{ng} / \mathrm{ml})$, and finally resuspended in $20-25 \mathrm{ml}$ of Tyrode/Hepes buffer containing $\mathrm{CaCl}_{2}(0.1 \mathrm{~mm}), \mathrm{MgCl}_{2}(1 \mathrm{~mm})$ and potato apyrase $(200 \mu \mathrm{g} / \mathrm{ml})$ (Siess et al., 1984b). Platelets were kept at $37^{\circ} \mathrm{C}$ and the platelet concentration was adjusted to $(6-7) \times 10^{8} / \mathrm{ml}$. Experiments were carried out between 30 and 90 minafter final resuspension. Platelet suspensions $(1.5 \mathrm{ml})$ were placed into aggregometer tubes, stirred (1100 rev./min) for $3 \mathrm{~min}$ at $37^{\circ} \mathrm{C}$ in the aggregometer and then exposed to vasopressin or DDAVP for various times. Light transmission was recorded and displayed on a chart recorder. Aliquots $(0.2 \mathrm{ml})$ were transferred into $0.75 \mathrm{ml}$ of chloroform/methanol $(1: 2, \mathrm{v} / \mathrm{v})$, and ${ }^{3} \mathrm{H}$ labelled platelet lipids were extracted, separated by thin-layer chromatography and measured as described previously (Siess et al., 1984b).

\section{Measurement of inositol phosphates}

Platelet-rich plasma from $50 \mathrm{ml}$ of blood was centrifuged after addition of prostacyclin $(300 \mathrm{ng} / \mathrm{ml})$ and the platelets were resuspended in $1 \mathrm{ml}$ of Tyrode/Hepes buffer containing $1 \mathrm{~mm}-\mathrm{MgCl}_{2}, 1 \mathrm{~mm}$-EGTA, apyrase $(100 \mu \mathrm{g} / \mathrm{ml})$ and $2 \mathrm{mCi}$ of $\left[{ }^{3} \mathrm{H}\right]$ inositol. The platelet suspension $\left[(2-2.5) \times 10^{9}\right.$ platelets $\left./ \mathrm{ml}\right]$ was incubated at $37^{\circ}$ for $3 \mathrm{~h}$ in aggregometer tubes while being stirred (250 rev./min). Prostacyclin $(500 \mathrm{ng} / \mathrm{ml})$ was added, and platelets were washed once in $8 \mathrm{ml}$ of Tyrode/Hepes buffer containing inositol ( $5 \mathrm{~mm}), \mathrm{CaCl}_{2}(0.1 \mathrm{~mm}), \mathrm{MgCl}_{2}$ $(1 \mathrm{~mm})$, heparin $(25$ units $/ \mathrm{ml})$, apyrase $(200 \mu \mathrm{g} / \mathrm{ml})$ and prostacyclin $(300 \mathrm{ng} / \mathrm{ml})$. After centrifugation, platelets were resuspended in 1.5-2 ml of Tyrode/Hepes buffer containing $\mathrm{CaCl}_{2}(0.1 \mathrm{~mm}), \mathrm{MgCl}_{2}(1 \mathrm{~mm})$ and apyrase $(200 \mu \mathrm{g} / \mathrm{ml})$. The platelet concentration was adjusted to $\left(1-1.3 \times 10^{9} / \mathrm{ml}\right.$. The platelet suspension was kept at $37^{\circ} \mathrm{C}$ for $30-45 \mathrm{~min}$ to reach equilibrium between the free $\left[{ }^{3} \mathrm{H}\right]$ inositol and the $\left[{ }^{3} \mathrm{H}\right]$ inositol incorporated into platelet phosphoinositides. Under those conditions the proportions of radiolabelled PtdIns, PtdIns4P and $P$ tdIns $(4,5) P_{2}$ obtained were $22.7 \pm 6: 3.3 \pm 0.8: 1$ (mean \pm S.D., $n=7$ ). Unlabelled phosphoinositides in platelets show similar proportions (Mauco et al., 1984). The specific radioactivity is thus equal for each radiolabelled platelet phosphoinositide and ranged between $15 \times 10^{6}$ and $100 \times 10^{6}$ c.p.m. of ${ }^{3} \mathrm{H} / \mu \mathrm{mol}$ of phosphoinositide in our experiments.

Samples of platelet suspension $(0.8 \mathrm{ml})$ were placed into aggregometer tubes, $\mathrm{LiCl}(10 \mathrm{~mm})$ was added and platelets were stirred for $3 \mathrm{~min}$ before exposure to vasopressin or DDAVP. Aliquots $(0.1 \mathrm{ml})$ were transferred at various times into $0.375 \mathrm{ml}$ of chloroform/

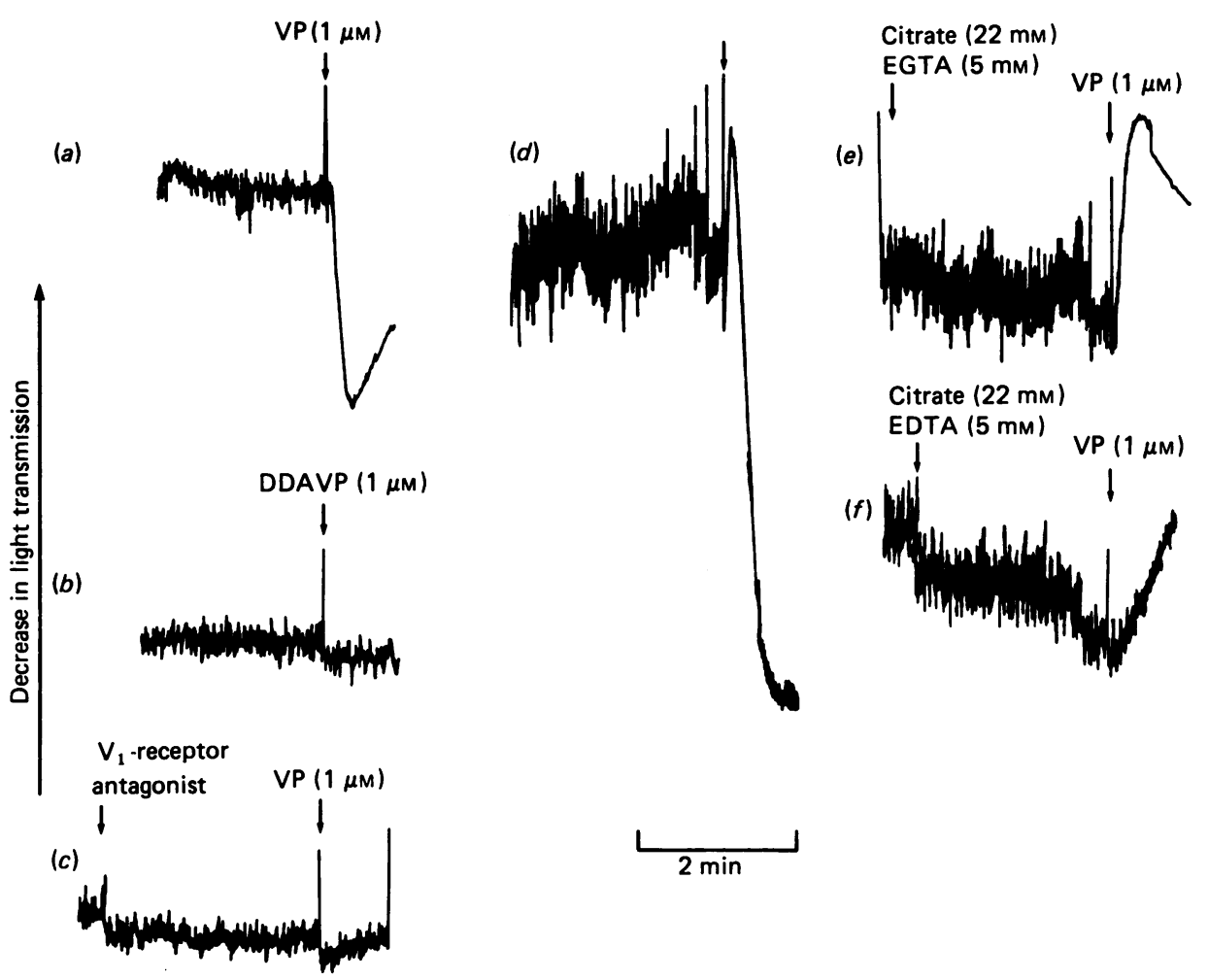

Fig. 1. Aggregation tracings of human platelets stimulated by vasopressin (VP)

Platelets prelabelled with $\left[{ }^{3} \mathrm{H}\right]$ inositol (Figs $1 a-1 c$ ) or $\left[{ }^{3} \mathrm{H}\right]$ arachidonic acid (Figs $1 d-1 f$ ) were resuspended in Tyrode/Hepes buffer containing $\mathrm{MgCl}_{2}(1 \mathrm{mM}), \mathrm{CaCl}_{2}(0.1 \mathrm{mM})$ and apyrase $(200 \mu \mathrm{g} / \mathrm{ml})$, and exposed to vasopressin $(1 \mu \mathrm{M})(a)$, DDAVP $(1 \mu \mathrm{M})(b)$, the $\mathrm{V}_{1}$-receptor antagonist D-(CH $)_{5} \mathrm{Tyr}(\mathrm{Me})$-AVP $(0.1 \mu \mathrm{M})$ plus vasopressin $(1 \mu \mathrm{M})(c)$, vasopressin $(1 \mu \mathrm{M})(d)$, citrate $(22 \mathrm{mM})$ plus EGTA $(5 \mathrm{mM})$ plus vasopressin $(1 \mu \mathrm{M})(e)$, citrate $(22 \mathrm{mM})$ plus EDTA $(5 \mathrm{mM})$ plus vasopressin $(1 \mu \mathrm{M})(f)$. Note that cells prelabelled with $\left[{ }^{3} \mathrm{H}\right]$ inositol respond to $1 \mu \mathrm{M}$-vasopressin with a reversible aggregation $(a)$, whereas platelets prelabelled with $\left[{ }^{3} \mathrm{H}\right]$ arachidonic acid respond with an irreversible aggregation $(d)$. 
methanol/conc. $\mathrm{HCl}(100: 200: 2$, by vol.). After addition of a mixture of unlabelled glycerophosphoinositol, inositol 1-phosphate, inositol 2-phosphate, inositol 1,4-bisphosphate and inositol 1,4,5-trisphosphate, which were prepared as described recently (Siess \& Binder, 1985; Binder et al., 1985), the aqueous soluble inositol phosphates were extracted (Siess \& Binder, 1985) and the samples were freeze-dried. The inositol phosphates were then separated by h.p.l.c. as described recently (Binder et al., 1985). fractions were collected, split into two halves and measured for ${ }^{3} \mathrm{H}$ radioactivity or for phosphorus (Bartlett, 1959). Radioactive inositol phospholipids were determined in separate samples by using extraction at acidic $\mathrm{pH}$ and $2 \mathrm{M}-\mathrm{KCl}$ (Billah \& Lapetina, 1982). They were separated on thin-layer plates impregnated with $1 \%$ potassium oxalate (Jolles et al., 1981).

\section{RESULTS}

\section{Vasopressin stimulates the formation of inositol} phosphates

Human platelets prelabelled with $\left[{ }^{3} \mathrm{H}\right]$ inositol were exposed to vasopressin $(1 \mu \mathrm{M})$, which induces shape change and reversible aggregation (Fig. 1a). Vasopressin stimulates the formation of four $\left[{ }^{3} \mathrm{H}\right]$ inositol-labelled compounds that co-chromatograph on h.p.l.c. with unlabelled inositol 1-monophosphate, inositol 2-monophosphate, inositol 1,4-bisphosphate and inositol 1,4,5trisphosphate (Fig. 2). Since in several experiments it was observed that inositol 2-monophosphate did not cochromatograph exactly with the $\left[{ }^{3} \mathrm{H}\right]$ inositol-labelled compound formed in vasopressin-stimulated platelets (see also Fig. 2c), a different h.p.l.c. system was set up to separate the following three inositol monophosphates: inositol 1-, inositol 2- and inositol 4-monophosphate. It was found that, in that system, the radioactive inositol monophosphates in control and vasopressin-stimulated platelets are co-eluted with inositol 1-monophosphate and inositol 4-monophosphate respectively (Fig. 3).

The formation of inositol bisphosphate and inositol trisphosphate is detectable $5 \mathrm{~s}$ after addition of vasopressin, whereas inositol 1-monophosphate and inositol 4-monophosphate increase after a time lag of $15 \mathrm{~s}$ (Figs. 2 and 4). The formation of inositol bisphosphate and inositol trisphosphate peaks at $30 \mathrm{~s}$ and then decreases. In contrast, inositol 1-monophosphate and inositol 4-monophosphate accumulate continuously during the time period tested (Fig. 4).

\section{Vasopressin stimulates the formation of 1,2-diacylglycerol and phosphatidic acid, and the production of arachidonate metabolites}

Human platelets prelabelled with $\left[{ }^{3} \mathrm{H}\right]$ arachidonic acid were exposed to vasopressin $(1 \mu \mathrm{M})$, which induces release reaction and irreversible aggregation (Fig. 1d). Vasopressin stimulates the rapid formation of 1,2-diacylglycerol and phosphatidic acid. 1,2-Diacylglycerol peaks before phosphatidic acid, indicating the sequential activation of phospholipase $\mathrm{C}$ and diacylglycerol kinase. Free arachidonic acid also increases immediately, but the formation of cyclo-oxygenase metabolites such as HHT and thromboxane $B_{2}$ is delayed by $20 \mathrm{~s}$. Metabolism by lipoxygenase to 12-HETE occurs even at later time points (Fig. 5).
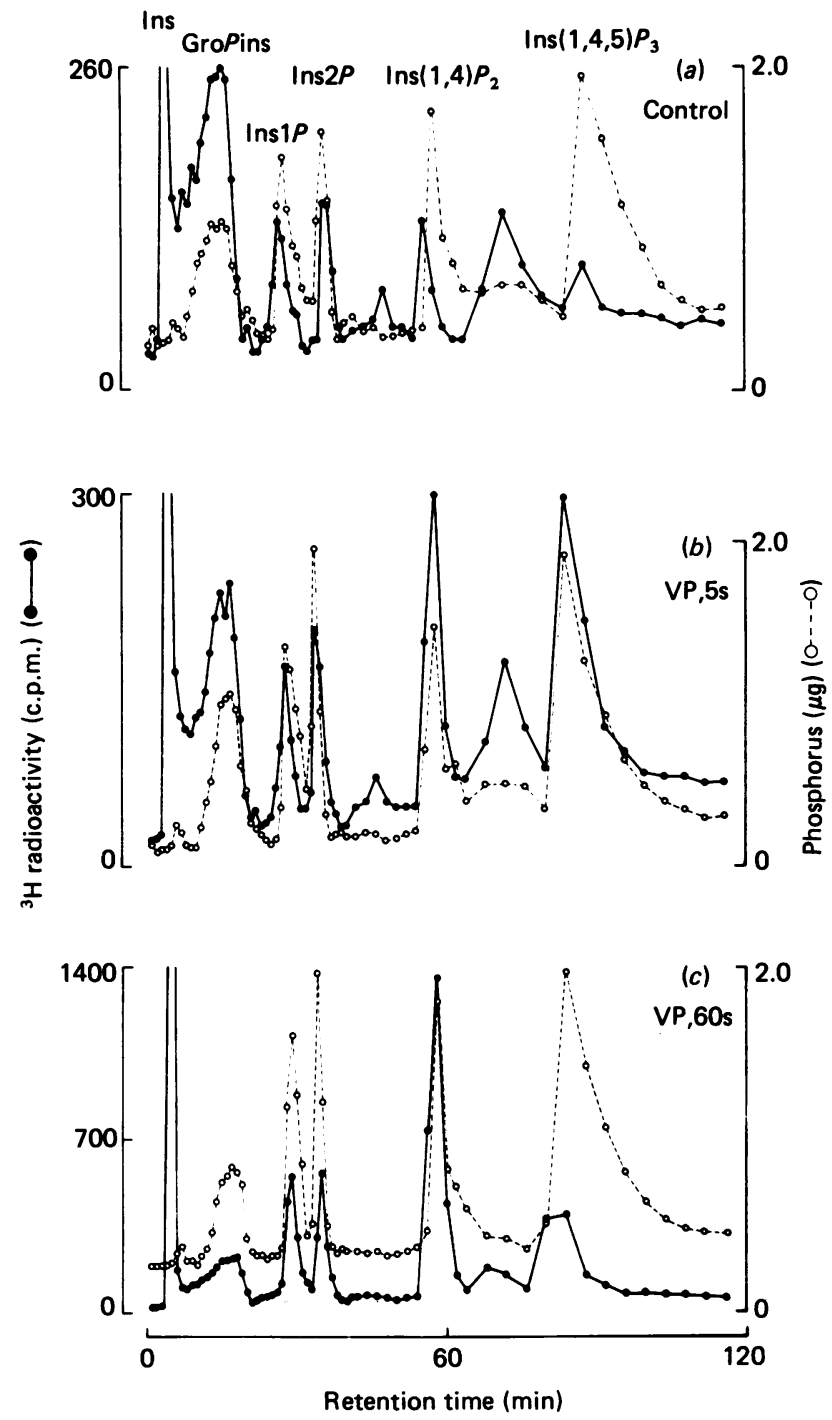

Fig. 2. H.p.l.c. separation of inositol phosphates formed in human platelets after exposure to vasopressin (VP)

Human platelets prelabelled with $\left[{ }^{3} \mathrm{H}\right]$ inositol were either exposed to saline $(a)$ or to vasopressin $(1 \mu \mathrm{M})$ for $5 \mathrm{~s}(b)$ or $60 \mathrm{~s}(c)$. Aliquots $(0.2 \mathrm{ml})$ of the platelet suspension were transferred into chloroform/methanol/HCl (Billah \& Lapetina, 1982), and a mixture of authentic unlabelled glycerophosphoinositol and inositol phosphates was added. The samples were extracted, separated by h.p.l.c. (Binder et al., 1985), and the fractions were measured for $\left[{ }^{3} \mathrm{H}\right]$ radioactivity $(O)$ and for phosphorus $(\mathrm{O})$. Incorporation of $\left[{ }^{3} \mathrm{H}\right]$ inositol into phosphoinositides of $0.2 \mathrm{ml}$ of platelet suspension was in this experiment 148400 c.p.m. for PtdIns, 29400 c.p.m. for PtdIns4P and 12390 c.p.m. for PtdIns $(4,5) P_{2}$. The recovery of the added standard compounds after extraction and h.p.l.c. was $39 \pm 6 \%$ for glycerophosphoinositol (GroPIns), $69 \pm 8 \%$ for inositol 1-phosphate (Ins1P), $71 \pm 8 \%$ for inositol 2-phosphate (Ins2P), $67 \pm 9 \%$ for inositol 1,4-bisphosphate $\left[\operatorname{Ins}(1,4) \mathrm{P}_{2}\right]$ and $51 \pm 1 \%$ for inositol $1,4,5$-trisphosphate $\left[\operatorname{Ins}(1,4,5) P_{3}\right]$. The abbreviations in the upper panel $(a)$ indicate the elution positions on h.p.l.c. of the added unlabelled standard compounds $(O)$. Only purified standard substances of defined chemical structure have been used. They were prepared as described by Siess \& Binder (1985) and Binder $e t$ al. (1985). Note the reduced scale of the left ordinate in $(c)$. 


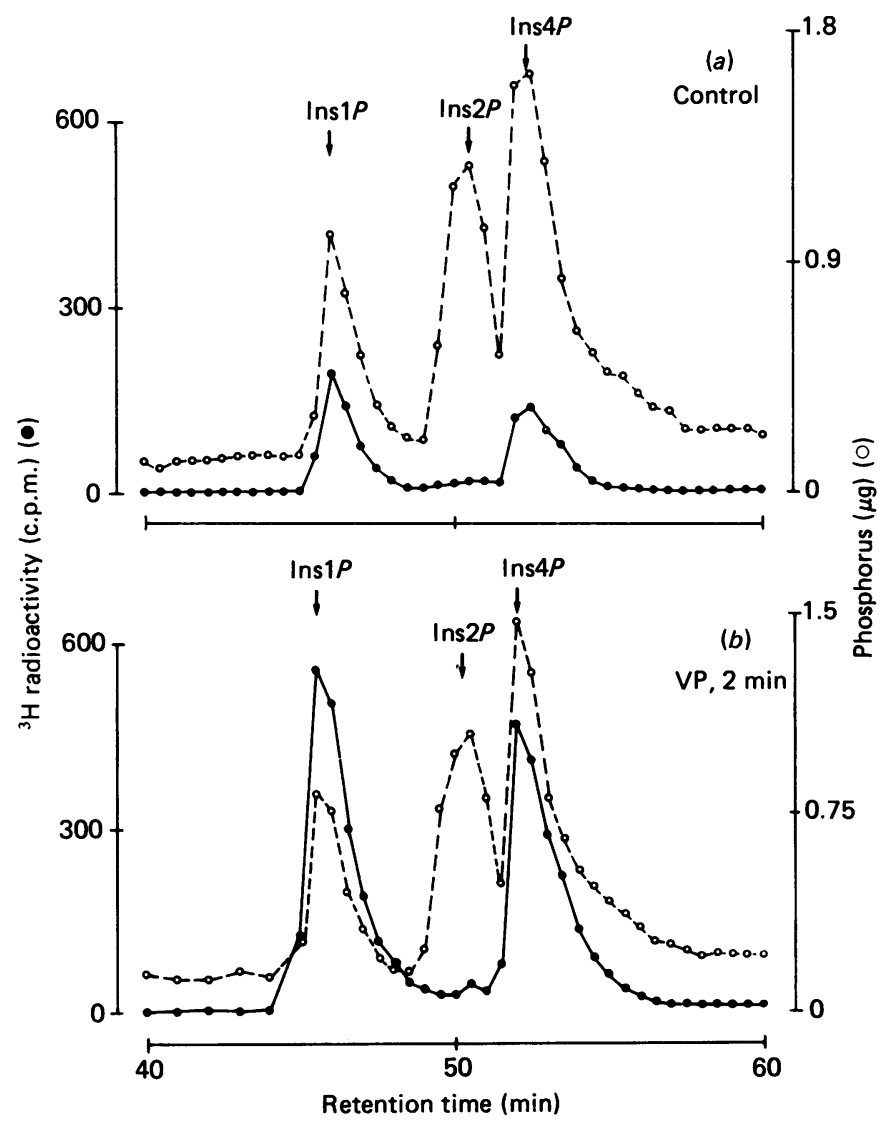

Fig. 3. H.p.l.c. separation of inositol monophosphates formed in platelets after exposure to vasopressin (VP)

Human platelets prelabelled with $\left[{ }^{3} \mathrm{H}\right]$ inositol were either exposed to saline $(a)$ or to vasopressin $(1 \mu \mathrm{M})$ for $2 \mathrm{~min}(b)$. Aliquots $(0.2 \mathrm{ml})$ of the platelet suspension were transferred into chloroform $/$ methanol $/ \mathrm{HCl}$ and a mixture of unlabelled inositol 1-monophosphate, inositol 2monophosphate and inositol 4-monophosphate prepared as described recently (Siess, 1985) was added. The samples were extracted and purified by Dowex anion-exchange chromatography (Berridge, 1983). The fraction containing the inositol monophosphates was passed through Dowex HCR-W2 columns (Siess \& Binder, 1985) and separated by h.p.l.c. on a freshly conditioned LiChrosorb $\mathrm{NH}_{2}$ column (Merck, Darmstadt, Germany) as described recently (Siess, 1985). Separation was carried out by utilizing a $20 \mathrm{~min}$ isocratic elution with $50 \mathrm{~mm}$-ammonium acetate/acetic acid buffer, $\mathrm{pH}$ 4.0, followed by a 60 min linear gradient to $1 \mathrm{M}$-ammonium acetate/acetic acid, $\mathrm{pH} \mathrm{4.0,} \mathrm{at} \mathrm{a} \mathrm{flow}$ rate of $1 \mathrm{ml} / \mathrm{min}$. Fractions were collected every $0.5 \mathrm{~min}$ and measured for radioactivity $(O)$ and for phosphorus (O). Abbreviations are defined in Fig. 2.

Low concentrations of vasopressin (10-100 nM) induce platelet shape change and reversible platelet aggregation without release reaction (results not shown). These concentrations only stimulate phospholipase $\mathrm{C}$, as indicated by the formation of 1,2-diacylglycerol and phosphatidic acid, without increasing the formation of arachidonate metabolites (Fig. 6). Only concentrations of vasopressin $(1 \mu \mathrm{M})$ that induce release reaction and irreversible aggregation stimulate both phospholipase $\mathrm{C}$ and the production of arachidonate metabolites (Figs. $1 d$ and 6).

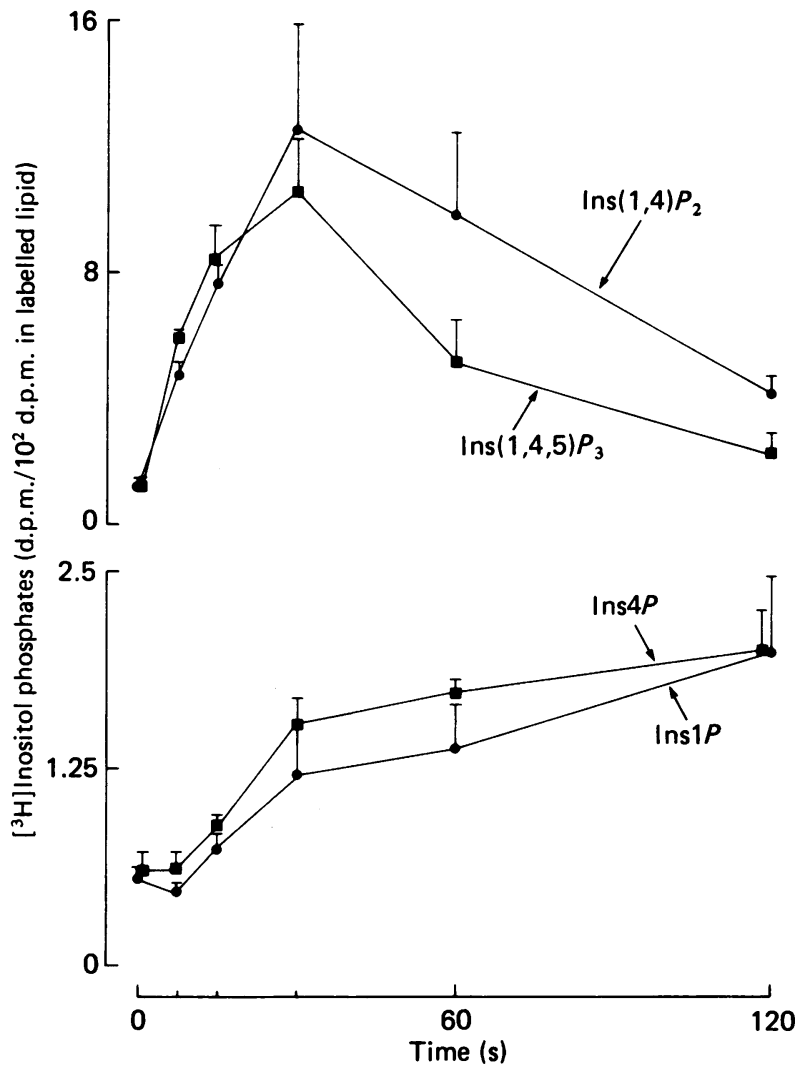

Fig. 4. Time course of formation of inositol phosphates in human platelets stimulated by vasopressin

Suspensions of human platelets [0.8 ml; $\left(1-1.3 \times 10^{9}\right.$ platelets $/ \mathrm{ml}]$ prelabelled with $\left[{ }^{3} \mathrm{H}\right]$ inositol were exposed to vasopressin $(1 \mu \mathrm{M})$ for various times. Aliquots $(0.1 \mathrm{ml})$ were transferred into chloroform $/ \mathrm{methanol} / \mathrm{HCl}$, a mixture of unlabeled inositol phosphate standards was added, two samples were pooled, and ${ }^{3} \mathrm{H}$-labelled inositol phosphates were measured after extraction and separation by h.p.l.c. as shown in Fig. 2. The radioactivity of each phosphate ester was corrected to a standard incorporation of $10^{2}$ d.p.m. of $\left[{ }^{3} \mathrm{H}\right]$ inositol into the respective platelet inositol phospholipids. The values are means \pm S.E.M. $(n=3)$. For abbreviations, see Fig. 2.

Effect of cyclo-oxygenase and lipoxygenase inhibition, and influence of extracellular bivalent cations on the action of vasopressin on platelets

Platelets that only respond with shape change and reversible aggregation after exposure to vasopressin do not produce arachidonate metabolites (Fig. 6). Therefore indomethacin does not change the formation of inositol phosphates in platelets that are prelabelled with $\left[{ }^{3} \mathrm{H}\right]$ inositol and stimulated with $1 \mu \mathrm{M}$-vasopressin (Fig. $1 a$, Table 1).

Similarly, indomethacin does not alter the production of phosphatidic acid in platelets that are prelabelled with $\left[{ }^{3} \mathrm{H}\right]$ arachidonic acid and stimulated with low concentrations (10-100 nM) of vasopressin (results not shown). In experiments, however, in which vasopressin $(1 \mu \mathrm{M})$ induces the production of arachidonate metabolites and irreversible aggregation (Fig. 6), indomethacin (which inhibits cyclo-oxygenase) or BW $755 \mathrm{C}$ (which inhibits both cyclo-oxygenase and lipoxygenase) causes a reduction of the phosphatidic acid formation at later time 


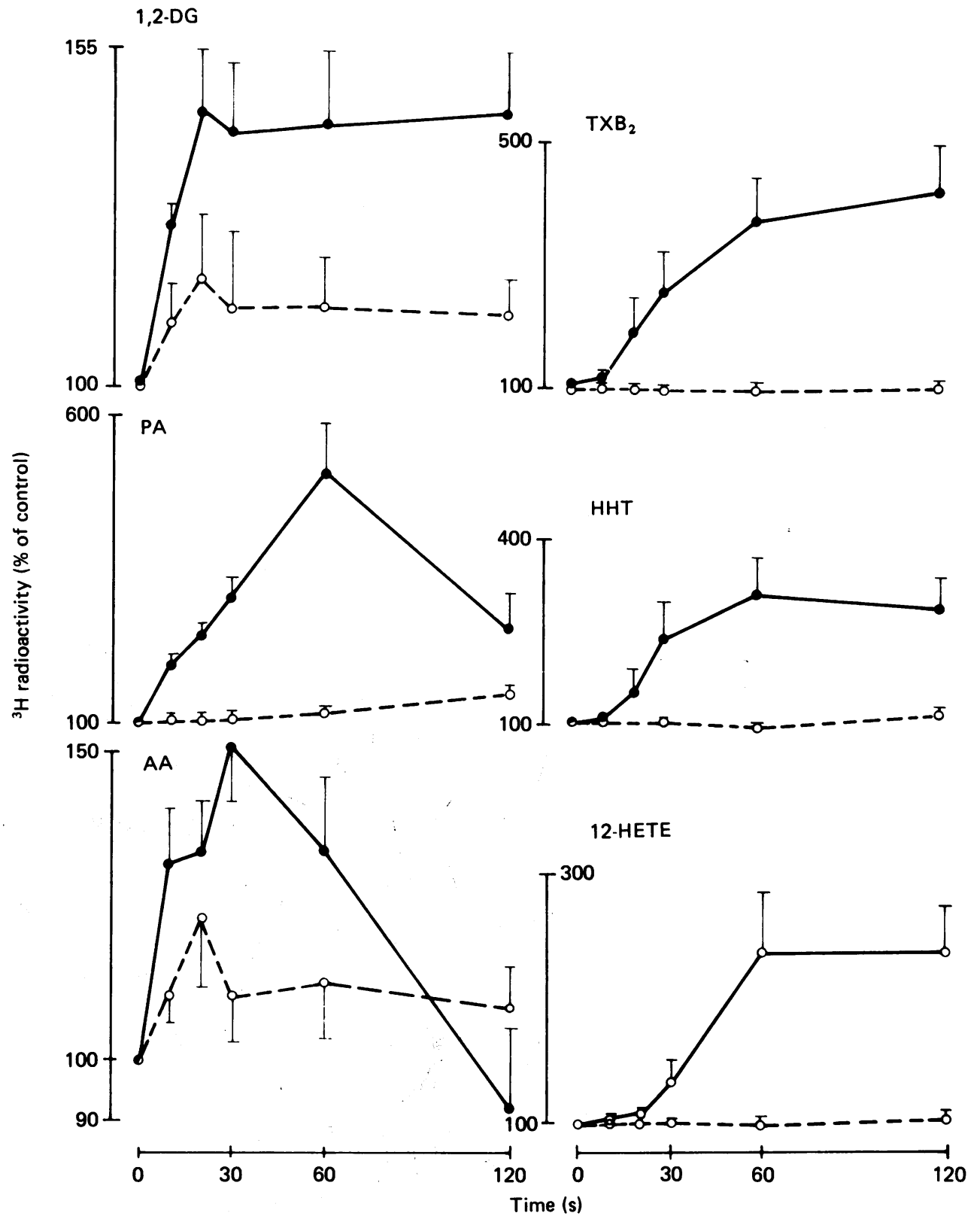

Fig. 5. Effect of vasopressin (O) and DDAVP $(O)$ on the formation of 1,2-diacylglycerol (1,2-DG) and phosphatidic acid (PA), the release of arachidonic acid (AA) and the production of arachidonate metabolites

Samples of platelet suspension $(1.6 \mathrm{ml})$ prelabelled with $\left[{ }^{3} \mathrm{H}\right]$ arachidonic acid were exposed to either $1 \mu \mathrm{M}$-vasopressin $(O)$ or DDAVP (O). Aliquots $(0.2 \mathrm{ml})$ were transferred at various times into chloroform $/ \mathrm{methanol}$ and ${ }^{3} \mathrm{H}$ radioactivity in platelet lipids was measured (Siess et al., 1984b). Values are means \pm S.E.M. from four experiments. Further abbreviation: TXB ${ }_{2}$ thromboxane $\mathbf{B}_{2}$.

points; the initial phospholipase $\mathrm{C}$ activation is, however, not affected (Fig. 7). In the presence of those inhibitors, release of serotonin does not occur and only reversible platelet aggregation is observed (results not shown).

The action of vasopressin on platelets is critically dependent on the presence of extracellular $\mathbf{M g}^{2+} . \mathbf{M g}^{2+}$ is needed for the shape-change and lipid responses induced by vasopressin, since chelation of $\mathrm{Mg}^{2+}$ abolishes completely the effect of vasopressin on platelet lipids and platelet responses (Fig. $1 f$, Table 2 ). $\mathrm{Ca}^{2+}$ is only required for the aggregation response, because the selective removal of extracellular $\mathrm{Ca}^{2+}$ only eliminates platelet aggregation, but does not significantly affect platelet shape change and lipid responses induced by vasopressin (Fig. 1e, Table 2).

Vasopressininduces platelet inositol phospholipid hydrolysis through activation of $V_{1}$-receptors

Preincubation of platelets with a $100 \mathrm{nM}$ concentration of the specific $\mathrm{V}_{1}$-receptor antagonist D- $\left(\mathrm{CH}_{2}\right)_{5} \mathrm{Tyr}(\mathrm{Me})$ AVP (Sawyer \& Manning, 1984) blocks completely the effect of vasopressin on platelet responses and inositol phosphate formation (Fig. 1c, Table 1). The $\mathrm{V}_{\mathbf{1}}$-receptor antagonist inhibits dose-dependently the formation of 


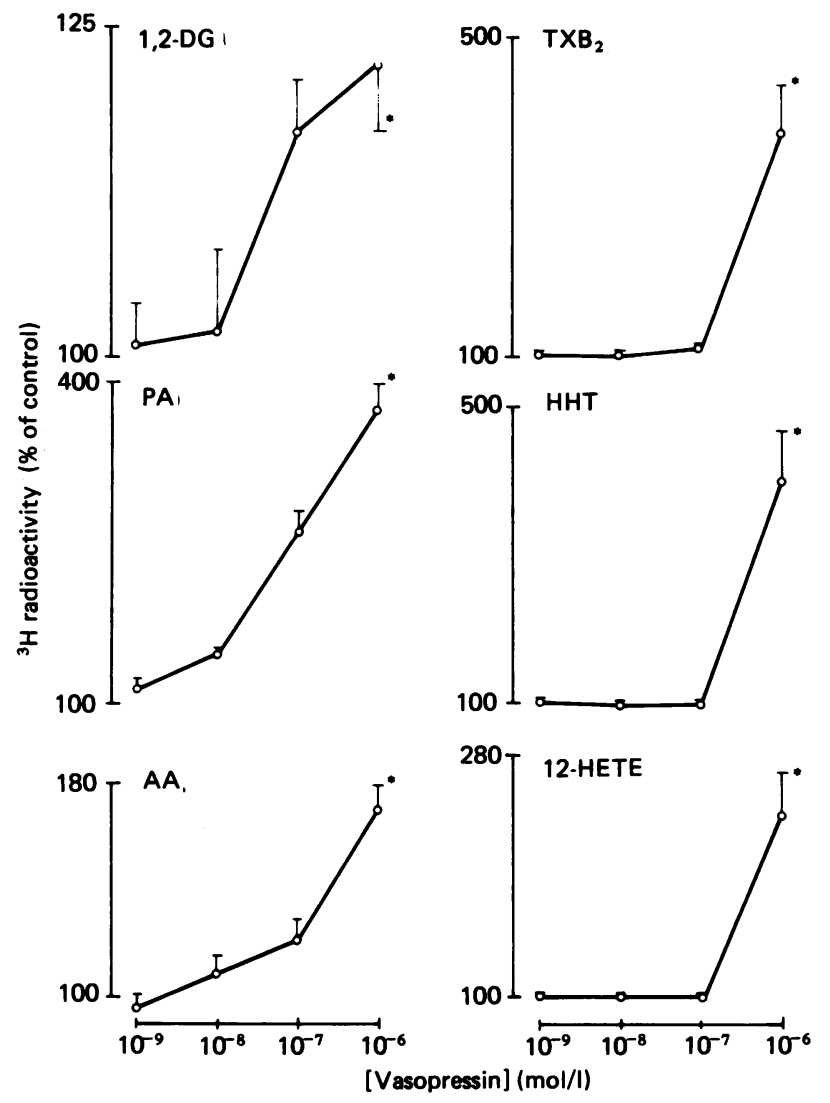

Fig. 6. Effects of various concentrations of vasopressin on phospholipase $\mathbf{C}$ activation and arachidonic acid metabolism in human platelets

Platelets prelabelled with $\left[{ }^{3} \mathrm{H}\right]$ arachidonic acid were exposed to vasopressin. 1,2-Diacylglycerol was measured $10 \mathrm{~s}$ after addition of vasopressin; phosphatidic acid and arachidonic acid were measured $30 \mathrm{~s}$, and arachidonate metabolites, $60 \mathrm{~s}$ after addition of vasopressin. Values are means \pm S.E.M. from six experiments. The asterisk $\left({ }^{*}\right)$ indicates irreversible platelet aggregation and release of $\left.{ }^{[14} \mathrm{C}\right]$ serotonin (Siess et al., 1983a) induced by $1 \mu \mathrm{M}$ vasopressin. For abbreviations see the legend to Fig. 5.

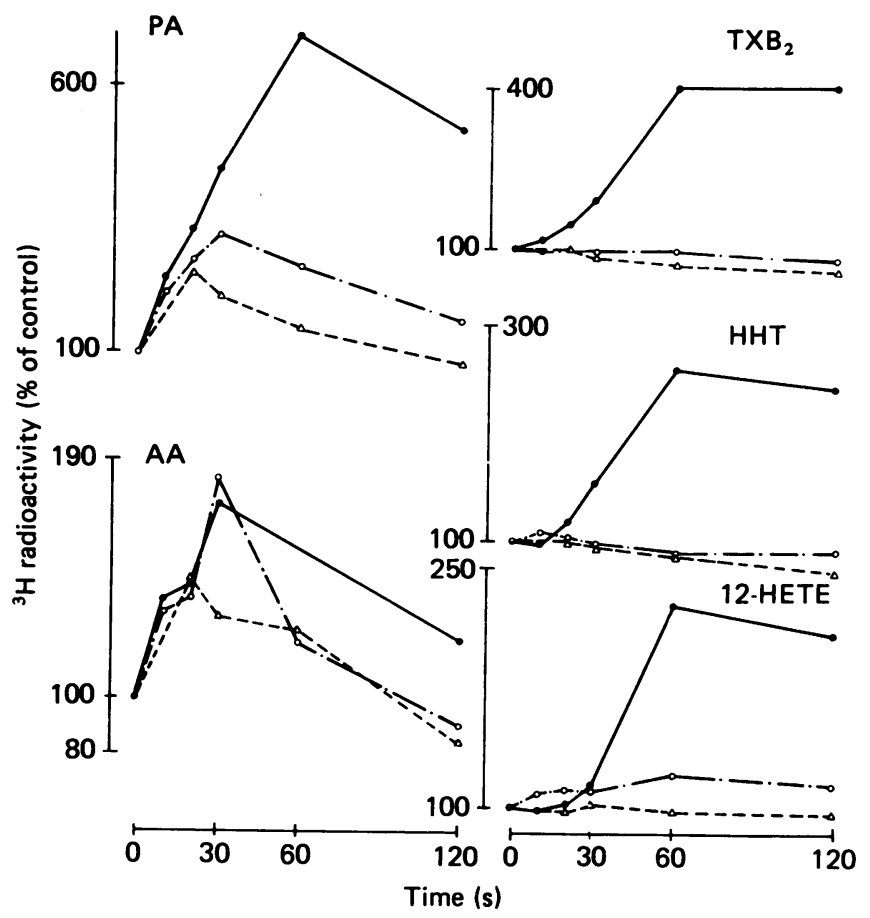

Fig. 7. Effects of indomethacin and BW755C on phosphatidic acid formation and arachidonic acid metabolism stimulated by vasopressin

Human platelets prelabelled with $\left[{ }^{3} \mathrm{H}\right]$ arachidonic acid were preincubated for $3 \mathrm{~min}$ at $37^{\circ} \mathrm{C}$ with $0.1 \%$ ethanol (O), indomethacin $(10 \mu \mathrm{M})(\mathrm{O})$ or BW $755 \mathrm{C} 100 \mu \mathrm{M}(\triangle)$, the latter two both dissolved in ethanol, before the addition of vasopressin $(1 \mu \mathrm{M})$. For further details, see the legend to Fig. 5.

phosphatidic acid in human platelets stimulated by $1 \mu \mathrm{M}$-vasopressin (Fig. 8). In addition, the vasopressin analogue DDAVP, which activates $\mathbf{V}_{2}$-receptors, does not induce platelet responses or the formation of inositol phosphates (Table 1, Fig. 1b). It also does not significantly enhance the formation of 1,2-diacylglycerol,

Table 1. Effect of DDAVP on the formation of inositol phosphates, and of indomethacin or a $V_{1}$-receptor antagonist on the vasopressin-induced formation of inositol phosphates in human platelets

Human platelets prelabelled with $\left[{ }^{3} \mathrm{H}\right]$ inositol were exposed to vasopressin or DDAVP for 1 min. The $\mathrm{V}_{1}$-receptor antagonist D- $\left(\mathrm{CH}_{2}\right)_{5}$ Tyr(Me)-AVP or indomethacin was added $3 \mathrm{~min}$ before vasopressin. Radioactive inositol phosphates were measured after h.p.l.c. as indicated in Fig. 2. The Table shows replicate values from one out of three different experiments which gave similar results.

${ }^{3} \mathrm{H}$ radioactivity (d.p.m.)

Additions

\begin{tabular}{ccccc}
\hline $\begin{array}{c}\text { Glycero- } \\
\text { phosphoinositol }\end{array}$ & $\begin{array}{c}\text { Inositol } \\
\text { 1-phosphate }\end{array}$ & $\begin{array}{c}\text { Inositol } \\
\text { 4-phosphate }\end{array}$ & $\begin{array}{c}\text { Inositol } \\
\text { 1,4-bisphosphate }\end{array}$ & $\begin{array}{c}\text { Inositol } \\
\text { 1,4,5-trisphosphate }\end{array}$
\end{tabular}

\begin{tabular}{|c|c|c|c|c|c|}
\hline \multirow[t]{2}{*}{ None } & 2023 & 869 & 669 & 228 & 77 \\
\hline & 2234 & 880 & 763 & 209 & 100 \\
\hline \multirow[t]{2}{*}{ Vasopressin $(1 \mu \mathrm{M})$} & 1958 & 2156 & 2189 & 1380 & 507 \\
\hline & 2654 & 1915 & 2010 & 1176 & 555 \\
\hline \multirow{2}{*}{$\begin{array}{l}\text { Vasopressin }(1 \mu \mathrm{M})+ \\
\text { indomethacin }(10 \mu \mathrm{M})\end{array}$} & 2302 & 2019 & 2056 & 1183 & 486 \\
\hline & 1995 & 2134 & 1804 & 1109 & 455 \\
\hline \multirow{4}{*}{$\begin{array}{l}\text { Vasopressin }(1 \mu \mathrm{M})+ \\
\mathrm{V}_{1} \text {-receptor antagonist }(100 \mathrm{nM}) \\
\text { DDAVP }(1 \mu \mathrm{M})\end{array}$} & 2615 & 858 & 747 & 245 & 39 \\
\hline & 2091 & 904 & 856 & 228 & 100 \\
\hline & 2239 & 747 & 634 & 235 & 47 \\
\hline & 2041 & 856 & 747 & 180 & 58 \\
\hline
\end{tabular}


Table 2. Effect of chelation of extracellular $\mathrm{Ca}^{2+}$ and $\mathrm{Mg}^{2+}$ on the action of vasopressin on platelet lipids

Samples $(1.0 \mathrm{ml})$ of human platelets prelabelled with $\left[{ }^{3} \mathrm{H}\right]$ arachidonic acid were resuspended in buffer containing $\mathrm{Ca}^{2+}(0.1 \mathrm{~mm})$ and $\mathrm{Mg}^{2+}(1 \mathrm{mM})$ and stimulated with vasopressin $(1 \mu \mathrm{M})$ for $1 \mathrm{~min}$. For chelation of extracellular $\mathrm{Ca}^{2+}$, citrate and EGTA were added 3 min before vasopressin. For chelation of $\mathrm{Ca}^{2+}$ and $\mathrm{Mg}^{2+}$, citrate and EDTA were added 3 min before vasopressin. Results are expressed as percentages of control (no addition of vasopressin) from three experiments (mean \pm s.d.). Further abbreviations: PA, phosphatidic acid; $\mathbf{T X B}_{2}$, thromboxane $\mathbf{B}_{2}$.

\begin{tabular}{|c|c|c|c|c|c|}
\hline Additions & PA & $\mathrm{TXB}_{2}$ & HHT & HETE & $\begin{array}{l}\text { Platelet aggregation } \\
\text { (\% light transmission) }\end{array}$ \\
\hline \multicolumn{6}{|l|}{ Vasopressin } \\
\hline $\begin{array}{l}\text { buffer } \\
\text { Vasopressin } \\
\text { + citrate }(22 \mathrm{mM})\end{array}$ & $\begin{array}{l}342 \pm 62 \\
239 \pm 19\end{array}$ & $\begin{array}{l}240 \pm 60 \\
178 \pm 49\end{array}$ & $\begin{array}{l}230 \pm 9 \\
212 \pm 67\end{array}$ & $\begin{array}{l}193 \pm 28 \\
192 \pm 35\end{array}$ & $\begin{array}{l}68 \pm 10 \\
15 \pm 2\end{array}$ \\
\hline $\begin{array}{l}\text { Vasopressin } \\
\text { + citrate }(22 \mathrm{~mm}) \\
\text { + EGTA }(5 \mathrm{mM})\end{array}$ & $279 \pm 35$ & $245 \pm 55$ & $203 \pm 28$ & $207 \pm 42$ & Shape change \\
\hline $\begin{array}{l}\text { Vasopressin } \\
+ \text { citrate }(22 \mathrm{mM}) \\
\text { + EDTA }(5 \mathrm{~mm})\end{array}$ & $117 \pm 12$ & $106 \pm 5$ & $98 \pm 17$ & $117 \pm 14$ & No activation \\
\hline
\end{tabular}

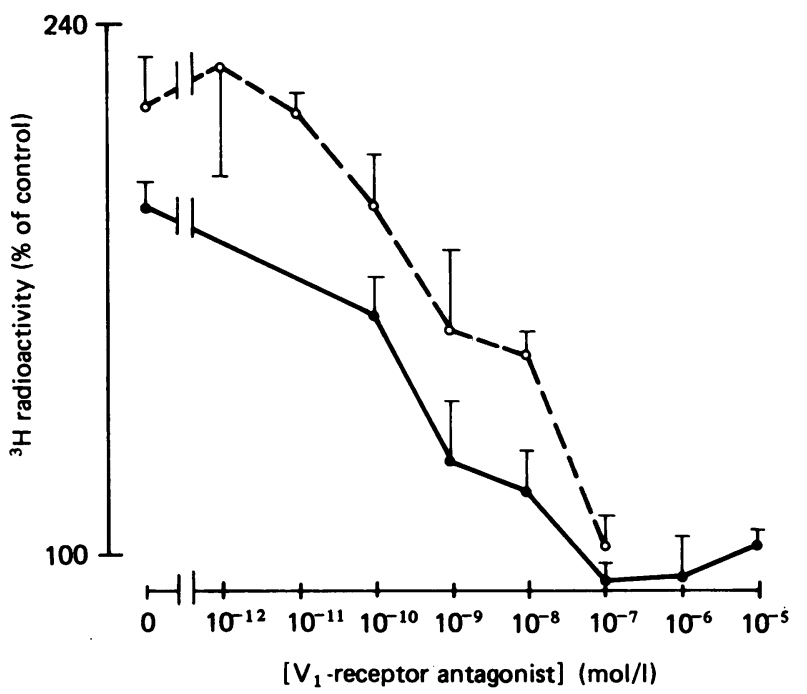

Fig. 8. Effects of various concentrations of the $V_{1}$-receptor antagonist D- $\left(\mathrm{CH}_{2}\right)_{5}$ Tyr(Me)-AVP on the formation of phosphatidic acid induced by vasopressin

Human platelets prelabelled with $\left[{ }^{3} \mathrm{H}\right]$ arachidonic acid were incubated with various concentrations of $\mathrm{D}-\left(\mathrm{CH}_{2}\right)_{5}$ $\operatorname{Tyr}(\mathrm{Me})$-AVP for $2 \mathrm{~min}$ at $37^{\circ} \mathrm{C}$ before incubation with vasopressin $(1 \mu \mathrm{M})$ for $1 \mathrm{~min}$. Values are means \pm S.E.M. from triplicate assays of two experiments from different platelet donors $(\mathrm{O}, \mathrm{O})$.

phosphatidic acid, arachidonic acid and arachidonate metabolites (Fig. 5).

\section{DISCUSSION}

The effect of vasopressin on inositol phospholipids has been studied mainly in hepatocytes (Kirk et al., 1977; Kirk et al., 1979; Billah \& Michell, 1979; Michell et al., 1979, 1981; Kirk et al., 1981 ; Prpic et al., 1982; Thomas et al., 1983, 1984; Litosch et al., 1983; Seyfred \& Wells, 1984; Hughes et al., 1984; Charest et al., 1985). Other tissues studied in which activation of $V_{1}$-receptors leads to the stimulation of inositol phospholipid metabolism include sympathetic ganglia (Bone et al., 1984) and aorta strips (Takhar \& Kirk, 1981). Our results indicate that, in platelets also, the activation of $V_{1}$-receptors is coupled to inositol phospholipid hydrolysis by phospholipase $\mathrm{C}$. Furthermore, $V_{1}$-receptor activation in platelets leads to release of arachidonic acid and production of arachidonate metabolites. The formation of inositol trisphosphate and diacylglycerol occurs immediately after platelet exposure to vasopressin, and those compounds are therefore formed rapidly enough to act as second messengers for platelet activation.

Inositol bisphosphate and inositol trisphosphate are formed before inositol monophosphates increase, indicating rapid hydrolysis of polyphosphoinositides. The formation of inositol bis- and tris-phosphate rapidly decreases thereafter, whereas inositol monophosphates continuously accumulate. These results may indicate that inositol monophosphates are partly produced by degradation of inositol tris- and bis-phosphates by specific phosphomonoesterases (Downes et al., 1982; Storey et al., 1984). Breakdown of inositol 1,4-bisphosphate by phosphatases would lead to a mixture of inositol 1-monophosphate and inositol 4-monophosphate. We observed that, in fact, two radioactive inositol monophosphates are formed in vasopressin-stimulated platelets, which co-chromatograph with inositol 1-monophosphate and inositol 4-monophosphate. The two inositol monophosphates are formed in almost equal amounts, which may indicate that the phosphatases remove the 1 - and 4-phosphate groups of inositol 1,4-bisphosphate at approximately similar rates. This suggestion is supported by the observation that the soluble phosphatase activity from liver does not show a precise positional selectivity for inositol 1,4-bisphosphate (Storey et al., 1984). These data could be an indication that inositol monophosphates formed in vasopressin-stimulated platelets, in contrast with platelets stimulated by thrombin (Siess, 1985), are entirely formed from inositol bisphosphate; they do, however, not rule out the possibility that phospholipase C-induced hydrolysis of PtdIns also occurs.

The results may indicate that both PtdIns4P and PtdIns(4,5) $P_{2}$ are degraded initially by phospholipase $C$ in platelets stimulated by vasopressin. It can, however, not be excluded that only $\operatorname{PtdIns}(4,5) P_{2}$ is degraded 
initially and that inositol 1,4-bisphosphate is formed from inositol 1,4,5-trisphosphate instead of from PtdIns4P. Support for this pathway comes from the observation that ${ }^{32}$ P-labelled PtdIns4P does not decrease after platelet activation with thrombin or endoperoxide analogue (Billah \& Lapetina, 1982; Rittenhouse, 1984). Formation of inositol polyphosphates before accumulation of inositol monophosphates has also been observed recently for hepatocytes stimulated by vasopressin (Thomas et al., 1984) and for platelets stimulated by thrombin, collagen and endoperoxide analogues (Watson et al., 1984; Vickers et al., 1984; Siess, 1985; Siess \& Binder, 1985; Watson et al., 1985).

In addition to inositol phospholipid hydrolysis by phospholipase $\mathrm{C}$, vasopressin also induces release of arachidonic acid from membrane phospholipids and the production of arachidonate metabolites in human platelets. The formation of arachidonate metabolites occurs subsequently to phospholipase $\mathrm{C}$ activation. Cyclo-oxygenase metabolites such as endoperoxides and thromboxane $\mathrm{A}_{2}$ are responsible for further activation of phospholipase $\mathrm{C}$, induction of release reaction and irreversible platelet aggregation, since cyclo-oxygenase inhibition reduces phosphatidic acid formation, inhibits release reaction and results in reversible platelet aggregation induced by vasopressin. Thus cyclooxygenase products play a role in amplifying platelet responses through phospholipase $\mathrm{C}$ activation (Siess $e t$ al., 1983a,b; Pollock et al., 1984; Siess et al., 1985; Watson et al., 1985). Low concentrations of vasopressin (10-100 nM) only induce phosphoinositide hydrolysis by phospholipase $\mathbf{C}$ and release of arachidonic acid without the production of arachidonate metabolites. A similar dissociation of phospholipase $\mathrm{C}$ activation from the production of arachidonate metabolites has been observed previously in platelets stimulated by low concentrations of thrombin, platelet activating factor and prostaglandin endoperoxide analogues (Siess et al., 1984b, 1985), and recently in fibroblasts stimulated by serum or bradykinin (Vicentini \& Villereal, 1984).

Inositol phospholipid hydrolysis, release of arachidonic acid and production of arachidonate metabolites in human platelets stimulated by vasopressin are mediated by the activation of $V_{1}$-receptor. DDAVP, a $V_{2}$-receptor agonist, does not induce these responses, and the observed platelet changes by vasopressin are blocked by a specific $V_{1}$-receptor antagonist. Our present findings indicate, therefore, that the $\mathrm{V}_{1}$-receptor present in human platelets is coupled to inositol phospholipid hydrolysis, release of arachidonic acid and production of arachidonate metabolites, and resembles the $V_{1}$-receptors found in hepatocytes and vascular smooth muscles.

\section{REFERENCES}

Ausiello, D. A. \& Zusman, R. M. (1984) Biochem. J. 220, 139-145

Bartlett, G. R. (1959) J. Biol. Chem. 234, 466-468

Berridge, M. J. (1983) Biochem. J. 212, 849-858

Berridge, M. J. (1984) Biochem. J. 220, 345-360

Billah, M. M. \& Michell, R. H. (1979) Biochem. J. 182, 661-668

Billah, M. M. \& Lapetina, E. G. (1982) J. Biol. Chem. 257, 12705-12708

Binder, H., Weber, P. C. \& Siess, W. (1985) Anal. Biochem. 148, 220-227

Bone, E. A., Fretten, P., Palmer, S., Kirk, C. J. \& Michell, R. H. (1984) Biochem. J. 221, 803-811
Broekman, M. J., Ward, J. W. \& Marcus, A. J. (1980) J. Clin. Invest. 66, 275-283

Butlen, D., Guillon, G., Rajerison, R. M., Jard, S., Sawyer, W. H. \& Manning, M. (1978) Mol. Pharmacol. 14, 1006-1017

Charest, R., Prpic, V., Exton, J. H. \& Blackmore, P. F. (1985) Biochem. J. 227, 79-90

Crause, P., Boer, R. \& Fahrenholz, F. (1984) FEBS Lett. 175, 383-386

Downes, C. P., Mussat, M. C. \& Michell, R. J. (1982) Biochem. J. 203, 169-177

Hallam, T. J., Thompson, N. T., Scrutton, M. C. \& Rink, T. J. (1984) Biochem. J. 221, 897-901

Haslam, R. J. \& Rosson, G. M. (1972) Am. J. Physiol. 223, 958-967

Hassid, A. \& Williams, C. (1983) Am. J. Physiol. 245, C278-C282

Hughes, B. P., Rye, K-A., Pickford, L. B., Barrit, G. J. \& Chalmers, A. H. (1984) Biochem. J. 222, 535-540

Jolles, J., Schrama, L. H. \& Gispen, W. H. (1981) Biochim. Biophys. Acta 666, 90-98

Kirk, C. J., Verrinder, T. R. \& Hems, D. A. (1977) FEBS Lett. 83, 267-271

Kirk, C. J., Rodrigues, L. M. \& Hems, D. A. (1979) Biochem. J. 178, 493-496

Kirk, C. J., Michell, R. H. \& Hems, D. A. (1981) Biochem. J. 194, 155-165

Lapetina, E. G. (1982) J. Biol. Chem. 257, 7314-7317

Lapetina, E. G. \& Cuatrecasas, P. (1979) Biochim. Biophys. Acta 573, 394-404

Lapetina, E. G. \& Siess, W. (1983) Life Sci. 33, 1011-1018

Lieberthal, W. \& Levine, L. (1984) Kidney Int. 25, 776-780

Litosch, I., Lin, S.-H. \& Fain, J. N. (1983) J. Biol. Chem. 258, 13727-13732

MacIntyre, D. E. \& Pollock, W. K. (1982) Br. J. Pharmacol. 77, 466P

Mauco, G., Dangelmaier, C. A. \& Smith, J. B. (1984) Biochem J. 224, 933-940

Michell, R. H., Kirk, C. J. \& Billah, M. M. (1979) Biochem. Soc. Trans. 7, 861-865

Michell, R. H., Kirk, C. J., Jones, L. M., Downes, C. P. \& Creba, J. A. (1981) Philos. Trans. R. Soc. London Ser. B 296, 123-137

Nishizuka, Y. (1983) Trends Biochem. Sci. 8, 13-16

Pfeilschifter, J., Kurtz, A. \& Bauer, C. (1984) Biochem. J. 223 , 855-859

Pollock, W. K., Armstrong, R. A., Brydon, L. J., Jones, R. L. \& MacIntyre, D. E. (1984) Biochem. J. 219, 833-840

Prpic, V., Blackmore, P. F. \& Exton, J. H. (1982) J. Biol. Chem. 257, 11323-11331

Rittenhouse, S. E. (1984) Biochem. J. 222, 103-110

Rittenhouse-Simmons, S. (1979) J. Clin. Invest. 63, 580-587

Sawyer, W. H. \& Manning, M. (1984) Fed. Proc. Fed. Am. Soc. Exp. Biol. 43, 87-90

Seyfred, M. A. \& Wells, W. W. (1984) J. Biol. Chem. 259, 7666-7672

Siess, W. (1985) FEBS Lett. 185, 151-156

Siess, W. \& Binder, H. (1985) FEBS Lett. 180, 107-112

Siess, W., Cuatrecasas, P. \& Lapetina, E. G. (1983a) J. Biol. Chem. 258, 4683-4686

Siess, W., Siegel, F. L. \& Lapetina, E. G. (1983b) J. Biol. Chem. 258, 11236-11242

Siess, W., Siegel, F. L. \& Lapetina, E. G. (1984a) Biochim. Biophys. Acta 801, 265-276

Siess, W., Weber, P. C. \& Lapetina, E. G. (1984b) J. Biol. Chem. 259, 8286-8292

Siess, W., Boehlig, B., Weber, P. C. \& Lapetina, E. G. (1985) Blood, 65, 1141-1148

Storey, D. J., Shears, S. B., Kirk, C. J. \& Michell, R. H. (1984) Nature (London) 312, 374-376

Streb, H., Irvine, R. F., Berridge, M. J. \& Schulz, I. (1983) Nature (London) 306, 67-69

Takhar, A. P. S. \& Kirk, C. J. (1981) Biochem. J. 194, 167-172 
Thomas, A. P., Marks, J. S., Coll, K. E. \& Williamson, J. R. (1983) J. Biol. Chem. 258, 5716-5725

Thomas, A. P., Alexander, J. \& Williamson, J. R. (1984) J. Biol. Chem. 259, 5574-5584

Thomas, M. E., Osmani, A. H. \& Scrutton, M. C. (1983) Thromb. Res. 32, 557-566

Vanderwel, M., Lum, D. S. \& Haslam, R. J. (1983) FEBS Lett. 164, 340-344

Received 10 May 1985/22 July 1985; accepted 3 September 1985
Vicentini, L. M. \& Villereal, M. L. (1984) Biochem. Biophys. Res. Commun. 123, 663-670

Vickers, J. D., Kinlough-Rathbone, R. L. \& Mustard, J. F. (1984) Biochem. J. 224, 399-405

Watson, S. P., McConnell, R. T. \& Lapetina, E. G. (1984) J. Biol. Chem. 259, 13199-13203

Watson, S. P., Reep, B., McConnell, R. T. \& Lapetina, E. G. (1985) Biochem. J. 226, 831-837 